\title{
ST PAUL'S ENCOUNTER WITH ATHENIAN STOICS AND EPICUREANS
}

\author{
J E Atkinson (Cape Town University)
}

The account in Acts 17 is approached from an historical point of view in the context of Athens' situation as an 'autonomous' city in a province of the Roman Empire. Despite the allusions to the trial of Socrates, the circumstantial evidence suggests that Paul was not formally put on trial, and if the hearing was more of a public debate then one might have expected more of a three-cornered exchange.

Commentaries on Acts 17 generally focus on Christological issues reflected in Luke's account of Paul's encounter with Stoics and Epicureans in Athens, and naturally treat the episode as a chapter in the history of Christianity, but the aim here is to approach the episode more from an historical point of view in the context of Athens' situation in a province of the Roman Empire. ${ }^{1}$ It is argued, if only in summary form, that Luke's text is not meant to be taken as referring to a formal trial, especially when one allows for literary influences and Luke's structuring of Paul's challenges in this period in Greece.

\section{Narrative elements}

Acts presents a series of episodes in Paul's visit to Greece, where locals confronted the apostle and tried to have local officials take action against him. The issues differed from case to case, which may have been historically correct, but the pattern suggests some narratological intent.

First in the sequence of episodes, Paul was in Philippi, perhaps in 49, and caused trouble for a group of men who made money from a slave woman who worked as a soothsayer. She was converted and cleansed of her pagan spirit. Her owners, Roman citizens, could have tried to seek redress by an action in terms of private law, but the legal issue would no doubt have been tricky, and the prospect of financial gain dim, so they took Paul and Silas off to the 'Roman' administrators (duoviri) to complain that these Jews were troublemakers and were teaching people to perform rites that decent Roman citizens could not respect (Acts 16.14-21). They were beaten and imprisoned, but promptly released and sent packing as soon as the magistrates realised that they were indeed Roman citizens (Acts 16.35-40). Here

This paper is a development from a small section of a talk I gave to a group of Catholics from St Michael's Church in Rondebosch to a group about to set off on a tour of Greece and Turkey 'In the steps of St Paul'. Note 60 infra carries a postscript. 
the complainants had tried a xenophobic line, and at the same time exploited the opportunity to display their adherence to Roman values. It is significant that the duoviri would have been members of the local Greek elite, who had been granted Roman citizenship and would therefore have been well aware that responsibilities attached to their special status.

Then in about AD 50, Paul was in Thessaloniki, where Luke says that he preached in the synagogue (Acts 17.1-2), but there is no evidence that there was a synagogue, and this may just be a narrative convention, or this is a reference to what in the Alexandrian context Philo calls meeting houses (Leg. ad Gaium 132: proseuchae). ${ }^{2}$ Here Jews opposed to Paul hauled him and his group off to face 'the people', but went instead to the administrators of the city, and this time they laid as well as the charge made in Philippi about Paul leading them into defiance of Roman law, ${ }^{3}$ the new charge that Paul and company were teaching that there was a new king, one Jesus (Acts 17.6-7). Again the officials seem to have let Paul and Silas slip away (Acts 17. 9-10).

There is perhaps a xenophobic element in this episode too in that members of the Jewish community first wanted to take their sectional dispute to a Greek assembly, but quickly saw more advantage in presenting their case to officials who had bought into the Roman system. Furthermore Claudius' initial policy of conciliation towards the Jews after the pogrom in Alexandria in $38^{4}$ was set aside in 49 after riots in Jerusalem led to police action that resulted in the death of at least 20000 Jews. ${ }^{5}$ Thus the Jews of Thessaloniki could help themselves by complaining about a troublemaker to the imperial agents.

From Thessaloniki Paul and Silas made their way to Athens, and there they engaged in discussion with Jews in the 'synagogue' and with anyone who would

2 Gruen 2002:110-119 notes that they also covered community, study and judicial functions.

3 An offence may have been alleged in terms of the maiestas law, or decrees enforcing oaths of loyalty (Dio 56.25.5-6; 57.15.8), or even measures against divination (Still 1999:76-78).

4 In November 41 the new emperor, Claudius, declined to adjudicate on the issue of responsibility for the start of the troubles. He nevertheless confirmed the special rights and concessions enjoyed by the Jewish community, but warned the Jews to live in harmony with the Greek community, and not to press for equal rights with the Greek community in the matter of the games and community festivals, and not to facilitate the infiltration into the city of Jews from Syria and Egypt. Inter-community tensions may have spread to Rome, which may explain why in the same year, and perhaps likewise in around the November of 41, Claudius took some action to control the Jews in Rome, allowing them to continue to live by their own customs, but denying them the right of assembly (Dio 60.6.6).

5 Josephus Ant. 20.112; Bellum 2.227. 
listen in the market place, or agora (Acts 17.17). Then at some point a group of Stoics and Epicureans, who would have been Greeks, took Paul off to the Areopagus to explain himself, as he seemed to be promoting the cult of strange gods (Acts 17.18-19). ${ }^{6}$ No action was taken against him, but he took himself off to Corinth.

There he met up with Aquila and Priscilla, who had been expelled from Italy when Claudius banished 'all Jews from Rome' (Acts 18.1-2). ${ }^{7}$ Paul spent 18 months in Corinth, and earned his living there as a tanner / leather worker in the tent-making business. At the same time he was busy preaching to Jews and gentiles, and when 'Christians' met it would have been in 'house-churches', perhaps in most cases provided by relatively wealthy locals, such as Gaius mentioned in Romans $16.23 .^{8}$

In Corinth Paul 'testified to the Jews that Jesus was Christ'(Acts 18.5). This fits in with the fact that the record of Claudius' expulsion draws in the first indication that by 49 Romans were aware that one Jesus was, or had been, a troublemaker in the Jewish community. Paul also bore witness to the resurrection of Christ (1 Cor. 15.3-8), which he later decided to de-emphasize (1 Cor . 2.2). He also campaigned against 'dumb idols' (1 Cor. 12.2). This was all heady stuff, and indeed in Corinth around 52 Paul was seen by most Jews as a troublemaker for urging Jews 'to worship God contrary to the law' (Acts 18.13). Then in 52, Gallio arrived as the new governor of Greece, based in Corinth (Acts 18.12). So Jews hostile to Paul hauled Paul off before Gallio. He dismissed the case, explaining that he would exercise his powers if the matter related to crime or immorality, but he would not judge on an issue of heresy. ${ }^{9}$ So this time the local Jews overplayed their hand by focussing on the more theological issue. But the governor showed some awareness of the strength of feeling in the Greek community by turning a blind eye when a crowd of Greeks beat up the chief rabbi in the actual courtroom (Acts 18.17).

Corinth was very much under Roman control as, from 44, the administrative centre of the province of Achaea. ${ }^{10}$ Roman influence is reflected in the high incidence of inscriptions in Latin, and the strong presence of the cult of the deified

See n. 15 infra.

7 This time there is reference to one Christ as having been the trouble-maker in Rome (Suet. Claud. 25.4 and Orosius 7.6.15-16), which may mean that the first Christian missionaries had arrived in Rome by 49 (on all the issues, Smallwood 1981:210-216).

$8 \quad$ Cf. Rom. 16.5; I Cor. 16.15.

9 Keener 2014:2760-2761 takes Acts 18.12-17 as fact.

10 With Claudius' reorganisation of the eastern provinces, putting Achaea back under the Senate's control (Dio 60.24.1). 
Julius Caesar and other members of the imperial family, plus the cult of Roma. Still, Gallio declined the opportunity to act against Paul's iconoclastic teaching.

Thus we have a well constructed sequence of four confrontations with new elements in each. There is also a narrative link between the phraseology in Acts 2.13 and 17.18. ${ }^{11}$ Indeed Haenschen made his mark in characterising Acts as an essentially literary work. He followed Dibelius in emphasising the significance of Paul's major speech to the Gentiles being set in Athens, but went beyond that by rejecting Dibelius' notion that Acts was written by one of Paul's companions and depended upon an Itinerary Source. ${ }^{12}$ And literary influences, or at least parallels, are now more commonly noted: here, for example, Acts 17.16 echoing the opening line of Achilles Tatius Leucippe and Cleitophon 1.1.2 as a topos of travel stories, and Acts 17.22-31 echoing the exchange between Timocles the Stoic and Damis, an Epicurean, in Lucian Iuppiter Tragoedus. ${ }^{13}$

It is not my concern here to reach a conclusion on the measure of poetic licence which Luke took in presenting this episode. It suffices here to assume that Luke expected the reader to find his account credible.

\section{Paul in Athens}

With this episode the key question is whether Luke means that Paul was submitted to a formal trial, even if it was only at the level of a preliminary hearing to decide whether there was an adequate case for a full trial. This hinges on what is meant by the action of the Stoics and Epicureans in taking Paul from the agora $^{14}$ to the Areopagus to explain himself, as he was apparently promoting the cult of strange gods (Acts 17.18). ${ }^{15}$ Under Roman influence the agora was not as it had been in the heyday of democracy, but the Areopagus, retained more of its original appearance, as it was sacred to Ares / Mars, and was where the council of elders used to meet.

11 Noted by Pervo 2009:427.

12 As noted for instance by Bechard 2000:70-72. I have not been able to consult directly Haenschen's Die Apostelgeschichte (Göttingen, 1956), nor its translation by Noble et al. The Acts of the Apostles (Philadelphia, 1971).

13 As noted by Pervo 2009:430-431, who also notes J H Neyrey's line on the possible influence of Josephus on Luke.

14 By this time the agora was not the same as it had been in the heyday of democracy in physical terms, for after Greece became a Roman province in $146 \mathrm{BC}$, and more particularly after Augustus set himself up as Emperor in $27 \mathrm{BC}$, the Athenian elite followed Roman fashion, and such public spaces became cluttered up with temples, especially in honour of Rome and Augustus (as the emperor of the day), and also with structures honouring local bigwigs.

15 In the 430's Diopeithes introduced a law that made it a criminal offence to refuse to believe in the gods or to propagate tales about heavenly bodies (Plut. Pericles 32.1). 
Originally they assembled in the open air, for the Areopagus heard cases involving willful murder: ${ }^{16}$ in cases of murder the verdict and sentence were delivered not only against the accused but also against the murder weapon, and the Areopagites could not be expected to risk contamination from the murderer and his weapon. Thus this area was more hallowed than the natural amphitheatre below, known as the Pnyx which was where the democratic assembly met. Such associations lingered, even after the Council meeting place was moved to the Stoa Basileios to the north west of the agora, and with arrival of the Principate the Areopagus was given more powers, with a status matching that of the Roman Senate, with extra powers added by Hadrian. ${ }^{17}$

But the question remains whether it was to this hilltop that a group of Stoics and Epicureans took Paul to defend himself, or at least explain himself, on his teaching. The preposition in Acts 17.19 \& $\pi$ í with the accusative case of the Areopagos does suggest that the writer thought of Paul as being taken up onto the Areopagus. But that preposition is used at Acts 16.19 and again at 17.6 of the actions of Paul's accusers in Philippi and then Thessaloniki in marching Paul off to face the local magistrates. So the preposition could mean either 'up (to)' or 'up before', and it is commonly assumed that at 17.19 the Areopagus refers to the Council of Areopagites, ${ }^{18}$ and, if this was the case, Paul would have been taken off to what was now their normal meeting place, the Stoa Basileios just off the main agora,${ }^{19}$ and indeed private citizens could traditionally initiate an action before the Areopagus council. ${ }^{20}$ On the other hand the expression used for Paul's departure from the gathering at 17.33 does not suggest that this was a formal trial. And indeed the first step in the formal procedure would have been for the would-be prosecutors to approach the archon basileus as the presiding officer of the Areopagus to request permission to initiate a prosecution. This preliminary hearing (anakrisis) had an inquisitorial element, whereas the main trial was adversative in

16 Andocides 1.78.

17 Swain 1996:74-75. The standing of the Council is indicated by the status of Flavius Euphanes (archon in the period 105-110), who was addressed as presiding officer of the Areopagus by Plutarch in his essay Should old men take part in politics? (Mor. 794b) written in the period 115-120 (Swain 1996:184). The raising of the status of the Areopagus is perhaps reflected in Chariton Callirhoe 1.11 on the fierceness of the Areopagites, as noted by Pervo 2009:427.

18 So, for example, Barnes 1969:413. Rowe 2009:29 also stresses the legal connotations of the participle غ́лı $\lambda \alpha \beta$ ó $\mu \varepsilon v o$ (Acts 17.19).

19 For that the writer could have used the preposition to/into, as in Lucian Anacharsis 19. Admittedly at 17.22 Paul appears 'in the middle of the Areopagus', though I would take it to mean 'in this meeting on the Areopagus'. Paul starts by addressing the crowd as Athenians and not as 'gentlemen of the jury' (i.e. Areopagites).

20 Even on a private matter (as at Demosthenes 58.29). 
manner. If permission was refused at the preliminary stage, then the process was halted. The writer could have used the term anakrisis, if he wished, as he uses it further on at Acts 25.26.

Thus Luke may have intended the reader to assume that there was some formal hearing, but the reality may still have been that a group of philosophers took Paul up onto the Areopagus for what amounted to a public debate. ${ }^{21}$ The setting was intended to emphasize the serious intent of these public intellectuals and to intimidate Paul. The symbolism is clear and significant if reference is made to the three dramatic impiety trials in Athens in $400 / 399 \mathrm{BC}$ - the trials of Socrates, Andocides and Nicomachus. But, although the issue in each case was impiety (asebeia) these trials were before a popular court and not the Areopagus. ${ }^{22}$ In this stressed situation after the restoration of democracy, the prosecutors were out to make the point that the alleged offences were all politically motivated, with an intent to subvert the reconstituted democracy. ${ }^{23}$ Thus, while the case against Socrates came under the impiety label, and the detailed charges included his refusal to believe in the god's of the city or belief in alien gods, the key phrase $\mu$ iे

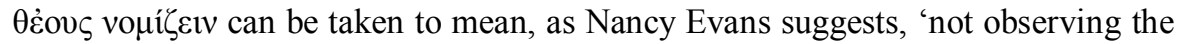
city's laws and customs concerning the gods'. ${ }^{24}$ Paul's challengers were unlikely to get very far by suggesting that Paul had some grand ambition to subvert the political order and chose to confront him on his religious ideas, while suggesting that his teaching was hostile to the norms of the Graeco-Roman Athenians. Luke certainly introduced elements into his story that invoked memories of the trial of Socrates, ${ }^{25}$ but it seems less likely that Paul's challengers would have wished to accord him the honour of appearing as a second Socrates.

21 Thus Blaiklock 1959:139: 'not a trial in the judicial sense of the word'; $c f$. Marshall 1980:285: 'a meeting of the court, no doubt in public session and not necessarily taking the form of a legal trial'; Keener 2014:2602-2603 argues that there was some formal procedure, perhaps 'a licensing hearing', with notes 2968 and 2995. Preece 2013:34-46 provides a good survey of the different views on this matter. It will be seen that my approach is in line with Kingsley Barrett's view that Paul received a 'kind invitation' to explain his doctrines in a form of public debate.

22 On this sequence of trials, Ostwald 1986:528-536. In Athenian law trials for impiety followed the procedure of eisangelia, and not dike, and thus signalled that there was some threat to the democracy.

23 In the case of Socrates he was found guilty of impiety, by a small majority, but at the second stage the vote in favour of the death sentence was carried by a far greater majority because of his effrontery in proposing as a counter-sentence that he should be granted free elite accommodation and board for the rest of his days.

${ }_{25}$ Cf. Rowe 2009: esp. 31-32. 
As indicated, the notorious impiety trials of 400/39 had much to do with protecting the structures and customs that underpinned the Athenian democracy, and while much changed over time, it is perhaps significant that after Cleisthenes introduced the system based on ten tribes each made up of three trittyes from three different regions of Attica (the city, the inland and coastal areas), each trittys made up of demes calculated to give each tribe roughly the same number of citizens, the number of demes rose by only three, up to the time that Hadrian increased the number of tribes from twelve to thirteen in 127/8, and added a new deme, labelled Antinoeis. ${ }^{26}$ Demes were the key element in the proportional representation system, and functioned in the liturgical system which provided a measure of material support for the poorer members of the citizen body. Then, of more immediate relevance, demes functioned as community centres built around the cults for which they were responsible. This is not to suggest that they made any significant contribution to theological debate or provided any real religious experience, except presumably for a few: but no doubt they served a purpose as do wedding ceremonies and more particularly funeral services in modern secular societies. Thus any serious threat to the preservation of the cultic functions of the demes might just have attracted an action before the Areopagus, but the account in Acts does not suggest that the philosophers had any such applied concern.

Likewise, while Acts 17.19-20 might be taken as an allusion to the legal requirements for any herald proposing the introduction of a new god (viz establishing the reality of the god's existence, the form of the recognition to be adopted, and the availability of a suitable slot in the calendar of feasts ${ }^{27}$ ), the speech attributed to Paul does not suggest that the focus was on such technicalities. Then, as Morgan suggests, since the Stoics and Epicureans had ideas that were 'divorced from the conventions of 'everyday society', ${ }^{28}$ they would probably have preferred to have the issues discussed at some higher court than had heard those earlier trials for impiety, or, if this was not a formal judicial proceeding, at some loftier venue in terms of its associations.

\section{New gods and divine rulers}

Athens had a history of tolerance of alien cults, either when the cult had a following way beyond its traditional bounds - thus the cult of Ammon of Siwah, or when a community in Attica sought permission to set up a shrine in honour of its patron deity - as when the Thracian community was allowed to establish a cult of

\footnotetext{
26 Traill 1975:76 and 103.

27 As noted by Winter 2015:146.

28 Morgan 2007:334.
} 
Bendis, ${ }^{29}$ or when a cult had some spiritual significance for some Athenians as with the Phrygian rites in honour of Sabazius. ${ }^{30}$

But this tolerance was certainly tested when Athens came under the control of Macedon, and when towards the end of Alexander's life Athens had been asked to establish the cult of Alexander and when the Areopagus was debating this issue, Demosthenes was reputed to have said in the Assembly that Athens should yield on the matter, whether Alexander also wanted to be the son of Zeus and Poseidon, or anyone else, and so allow a statue of Alexander as king and god invisible. ${ }^{31}$ Demosthenes' known attitude to Alexander made it clear that this was just a pragmatic move to avert unnecessary trouble, and was not meant to have any serious religious significance. ${ }^{32}$

But the problem arose again after Greece became a Roman province in 146 $\mathrm{BC}$ and more particularly after Julius Caesar aspired to divine status, and Augustus elected to style himself the son of the deified Augustus.

The story of the introduction of Roman ruler cult into Athens shows that it was a slow and uneasy process. The fact that the first High Priest of Caesar appears to have been recognised by the allocation to him of the front row seat in the Theatre of Dionysus in the Augustan era is of some significance as the main attraction of the Theatre was or became the gladiatorial games. ${ }^{33}$ The games surely did not provide much of a religious experience for those who sought it. Then Pammenes, an Athenian aristocrat, as priest of the goddess Roma and Augustus Caesar is mentioned in the dedicatory inscription of the Temple of Roma and Augustus on the Acropolis, dateable to 21-18 BC. ${ }^{34}$ But Athens was generally rather troublesome for Augustus (Plut. Mor. 207e), and this culminated in AD 13 when the faction most hostile to Rome took up arms, but was soon dealt with and the leaders were executed.$^{35}$ It was then propitious for Athenians with aspirations to make more effort to show dedication to the imperial family, which may explain the increase in dedications supporting ruler cult.

29 Strabo 10.3.18; $I G \mathrm{II}^{2} 1283$; $c f$. the grant to Citian traders to build a shrine to Isis in the Egyptian manner: $\mathrm{I} G \mathrm{II}^{2} 337$.

30 Strabo 10.3.18; $I G I^{2} 2932$ for priests of Sabazius at the Peiraeus in 342/1, rites mocked by Demosthenes 18.259-260.

31 Hyperides Against Demosthenes 31-32; cf. Dinarchus Against Demosthenes 94 and Aelian Varia Historia 2.19.

32 For the contrast, Demades was punished for proposing that Alexander be added to the Olympian gods, as he had been a steady campaigner for accommodation with Alexander (Aelian Varia Historia 5.12; cf. D.S. 18.18.2).

33 Dio Chrysostom 31.21; Spawforth 1997:183-184; IG II 5034.

34 Geagan 1997:23.

35 Orosius 6.22.2; Bowersock 1965:106-107. 
It can be accepted that there may have been people who in various contexts were moved to find a genuine acceptance of the superhuman nature of their beloved leader, ${ }^{36}$ while others could as easily be moved to mock, as in Seneca's Apocolocyntosis. Hero worship surely depended on some personal perception of a ruler's charisma. Imposed ruler cult was more likely to advance the secularisation of society.

\section{Paul's challengers}

Luke introduces the challengers as some Epicureans and Stoics, which may imply that when they took him to the Areopagus they were acting as individuals and not as official representatives of their respective schools. Indeed one did not have to be a 'seminarian' to be a Stoic or Epicurean, and again one might be like the Stoic Euphrates of Tyre, who claimed that although he had always lived with philosophers, he had studiously avoided appearing like the stereotypical philosopher. ${ }^{37}$

From the start the Stoics enjoyed tolerance from the Athenians. Admittedly, sometime in the period of Antigonus' suzerainty (306-301 BC) Cleanthes went to Athens and was at some point brought before the court of the Areopagites. Much later he took over from Zeno as head of the school of Stoics after Zeno died in 263, but the hearing before the Areopagites had nothing to do with anything as serious as his Stoic beliefs, but more to do with his status and employment. ${ }^{38}$ The famous hymn he composed to celebrate Supreme Reason under the name of Zeus shows how he could adapt his philosophical creed to make it acceptable to those grounded in the traditional cults of the city. ${ }^{39}$ Stoics, like some other philosophers who were active teachers continued to be respected, as shown for example by the inscription of 122/1 BC commending ephebes to Stoics, Academics and Peripatetics as teachers ${ }^{40}$ and individuals could be honoured for their role as intellectuals, or at least as fairly harmless eccentrics. So in the immediate context they are perhaps to be recognised as respected public intellectuals, thus more readily accepted by the Areopagites, some perhaps already members of that class themselves.

36 In our own day such adulation is displayed for example in North Korea, at least when so orchestrated in the capital city, but the attitude appears more spontaneously in the cult of celebrities, as seen in the 'beatification' of Princess Diana.

37 Epictetus Diss. Arr. 4.8.17-20; Jones 2003:160. Euphrates met Vespasian in Alexandria, was banished from Rome by Domitian, but returned under Nerva.

38 Diogenes Laertius 7.5.168-169, albeit showing that his studying under Zeno might have come into the equation.

39 Text, translation and commentary in Thom 2005.

$40 I G I^{2} 1006$. And for this as a more general feature of Greek cities, $S E G$ 57, 2007: no. 2138, summarising references in Haake 2007. 
In Athens, there was more uneasiness about Epicureans, witnessed for example by their absence from the 'philosophic embassy' sent to Rome in $155 \mathrm{BC}$, and as it happened the expulsion of two Epicureans from Rome in $154 \mathrm{BC}$ for promoting hedonism. ${ }^{41}$ This attitude may have changed in the era of the late Republic when Epicureanism was more acceptable in Rome. ${ }^{42}$ Then for all its emphasis on free will and freedom of speech, ${ }^{43}$ which may itself have been a vexing issue when the Principate was established, the Epicurean school became quite dogmatic, with Athens taking the lead in policing Epicurean orthodoxy, and sometime in the first century the Athenian school accepted the rule that its president had to have Roman citizenship, even if a Greek by birth. ${ }^{44}$

But as Greece came under more direct Roman control in the Principate, yet with more respect for its cultural heritage, the grant of free city status to Athens meant that the city fathers had to be the more careful to the play the system. Furthermore groups such as the Stoics and Epicureans would have been influenced by how the emperor of the day treated related groups in other communities, and in particular in Rome. Thus, for example, Stoics would have been more on the defensive after the trial of Thrasea Paetus for treason in 66 and Nero's action against other members of his family and coterie (Tac. Ann 16.33), and both Stoics and Epicureans would have been cautious after Vespasian banished all philosophers from Rome in $71,{ }^{45}$ and again after Domitian did the same in $93 .{ }^{46}$ But with the accession of Trajan philosophers could acclaim the restoration of freedom of thought for philosophers. ${ }^{47}$ Thus for example $T$ Flavius Pantaenus, 'priest of the philosophical Muses' could dedicate a library and its collection of books to Athena Polias and the Emperor Caesar Augustus Nerva Traianus Germanicus. ${ }^{48}$ It does not appear that the story of Paul's confrontation with the philosophers in Athens took place when the city was under any 'red alert', whether one takes this to be the assumed date of the event, or the now generally favoured

${ }^{41}$ Athenaeus 12.547a; 13.610e; $c f$. Aelian vh 9.12; and Frag. 42a. This was to ignore the Epicurean belief in the therapeutic value of Philosophy.

42 Cf. Jones 2009:523-524.

43 Gigante 1995:24-29.

44 Chandler 2006:5-8 and 122-123 on PHerc. 1674 col. LII.11-23. Then in AD 121 Plotina Augusta appealed to Hadrian to intervene in the succession issue relating to the presidency of the Epicurean School (secta) in Athens to allow the outgoing president to nominate to the general council of the school the most suitable candidate, without the restriction of Roman citizenship, and that the president should be free to submit his recommendation in Greek (IG II/III ${ }^{2}$ 1099; Smallwood 1966:157-158, no. 442).

45 Whitmarsh 1998:200.

46 Suet. Dom. 10.5; Tac. Agr. 2.1-2; Pliny. Ep. 3.11.2-3; Dio 67.13.3.

47 Pliny Pan. 47.1-2.

48 Smallwood 1966: no. 395; SEG xxi, 703, noted by Whitmarsh 1998:202. 
date of composition of the text of Acts, c. AD $115 .{ }^{49} \mathrm{~A}$ dramatic statement of an Epicurean's freedom to broadcast his views (and display his wealth) was the stoa which Diogenes set up in Oinoanda in the first half of the second century crowned by an inscribed text perhaps covering some 260 sq. metres. ${ }^{50}$

Whether or not the Athenian philsophers were formally attached to either school, they could presumably maintain a distinction between their role as philosophers and their activities as citizens, ${ }^{51}$ which may in turn suggest that this was a public debate, albeit at a lofty level, rather than a criminal action. They were self-assured enough to dismiss Paul as $\sigma \pi \varepsilon \rho \mu о \lambda$ ó $о$ o ( 'babbler': Acts 17.18), which implies that the Areopagites would readily accept that such a label would not apply to themselves.

\section{The Hearing}

In Acts 17. 24-26 Paul presents God as the aniconic creator of the world, and the source of all matter, the whole set to operate within fixed temporal and spatial boundaries. Stoics could have found Paul's representation of God acceptable, if we compare Cleanthes' Hymn to Zeus. And the expression in line 4, 'we are Thine offspring' is echoed by Paul in Acts 17.28..$^{52}$ The Epicureans would have been less likely to grant some poetic licence, as they were not creationists and promoted the idea that men were free to make choices as guided by reason. Epicurus was attracted to the atomic theory of the Ionian scientist Democritus, who hypothesized that in the beginning there were atomic particles in free fall which gradually coalesced to produce matter. This meant a form of determinism which did not appeal to Epicurus, who then modified the theory of atomic swerve by suggesting that atoms could diverge from their trajectory by a conscious act of volition. ${ }^{53}$ This aetiology was crafted to bolster the concept of free will as inherent

49 Thus Pervo 2009:5, over against a date of composition within the period c. AD 62-70, favoured by for example Blaiklock 1959:15-17, Marshall 1980.

so Hammerstaedt \& Smith 2014; Roskam 2007:129-144.

51 So Haake 2007, as noted with approval by Jones 2009. At the same time the interaction of Stoics with their communities gave each group something of its own identity, quite apart from the fissiparous factor that could lead to a city having separate schools reflecting different streams of thought. Thus Strabo refers to philosophers as having scholae (e.g. 17.3.22), diatribae $(9.1 .8 ; 17.1 .29)$.

52 Dibelius 2004 went as far as claiming that 'the main ideas of [Paul's] ... are Stoic rather than Christian', but this idea is systematically rejected by Rowe 2009:27-41.

53 As noted by Karl Marx; Bailey 1928. Epicurus' idea on the swerve is alluded to in Diogenes of Oinoanda, Frag. 54 in the edition of Smith 1963; cf. Bailey 1947: esp. 837842 on Lucretius 2.216-293; Cic. De nat.deorum 1.69. Pope 1986: esp. 77 and 84-86. Atkinson, 'Benjamin Farrington and the science of swerve', in South Africa, Greece and Rome: Classical confrontations (forthcoming). 
in the human condition. The removal of divine direction and divine providence ${ }^{54}$ allowed the pursuit of happiness, which in its debased form meant hedonism, but also put the onus on the individual to put service to society over personal ambition, thus to exercise free will responsibly. In this they were closer to the Stoics whose cardinal point was that the key to a tranquil, fulfilled life was to endeavour to stay within the bounds that fatum as reason dictated. And indeed there was a Stoic line that while the natural order argued for the creative force of providence, the diversity of the human race indicated the absence of determinism. ${ }^{55}$

The Stoics and Epicureans listening to Paul would not have been too worried about his dismissal of the gods of the Athenian pantheon. However, on the creation of the world Paul would have had a wonderful opportunity to set the Epicureans off against the mainstream Stoics, if we can judge by the way Diogenes attacked the Stoics on this subject in the inscription he set up for the people of Oinoanda to read. ${ }^{56}$

But they chose to tackle Paul on what he meant by the character of Jesus and the resurrection, as he appeared to be introducing strange gods. Their questioning implied that they were not trying to catch Paul out as being in conflict with the rites and practices that were trappings of the cultural norms of Athenian society, but rather to test him on metaphysical ideas that were closer to their own ideas on the nature of the universe. Their thinking was something of an intellectual exercise which they could pursue whilst staying in harmony with the requirements of Athenian citizenship. The nature of the challenge, the physical context of the exchange, the combination of Stoics and Epicureans in this event all suggest that this was more of a debate staged by public intellectuals than a serious juridical trial. It is tempting to see it as something akin to the sustained dialogue in Christian circles on the question 'Is God dead?' where the challenge is to anthropomorphic concepts of God.

Paul's iconoclastic line would obviously challenge the cults of the city, but could also be taken as a form of resistance to ruler cult. But the philosophers were not following such a track, as can be seen from the stark contrast between their approach and the legalistic agenda in Pliny's security report to Trajan in 98 on his investigation into what Christian practices were exercised in Christian groups in Bithynia. ${ }^{57}$

54 Hammerstaedt \& Smith 2014: esp. 161-162.

55 Dueck 2000:62-63, noting in particular Strabo 2.3.7.102-103.

56 Hammerstaedt \& Smith 2014:266-270, for NF 127 with frag. 20.I and II and NF 182.

57 Pliny's letter to Hadrian indicates that the real issue had more to do with enforcing the limitations on collegia than confronting new religious ideas, and in this regard there would not have been much of a problem until Christians moved to create house churches 
Pliny's letter to Trajan indicates that the real issue had more to do with enforcing the limitations on collegia than confronting new religious ideas, and in this regard there would not have been much of a problem until Christians moved to create house churches and group activities. Religious tolerance was allowed. ${ }^{58}$ This was seen in the way Greek officials avoided making an issue of Paul's teaching.

\section{Conclusion}

The author of Acts 17 does not suggest that Paul was taken to the court of the Areopagus if that meant for a hearing at the Stoa Basileios, and does not include elements that would reflect the normal procedure, starting with a preliminary hearing (anakrisis) by the presiding officer and ending with some formal decision. Thus the text seems rather to refer to some informal open assembly on the Areopagus, where a group of public intellectuals challenged Paul to explain himself, whether or not this could be labelled a public debate. For these philosopher / teachers nothing rode on this encounter, unlike the situation in the other three cases described in this account of Paul's time in Greece where complaints against Paul were lodged before local magistrates. ${ }^{59}$ Thus I have ventured to suggest that this episode can be seen as more like some stage in the protracted, post-Enlightenment debate in Christian circles on 'the death of God', ${ }^{60}$ which in some ways has echoes of the theorising of the Stoics and Epicureans in the classical period. ${ }^{61}$ More relevantly one can draw in the evidence that in the Graeco-Roman world in the first century, that Stoics and Epicureans were not under threat for whatever ideas they had about the origins of the universe and divinity, especially if as citizens they respected the norms and religious customs of

and group activities. Religious tolerance was allowed. This is seen in the way Greek officials avoided making an issue of Paul's teaching.

58 A few conversions are mentioned: Dionysius the Areopagite and a woman called Damaris, and others (Acts 17.34).

$59 \quad C f$. Fuhrmann 2012; esp. 3-4, with n.2 for source references.

60 One thinks of the work of Tillich and Bonhoeffer, or rather of more recent theologians, like the Bishop of Woolwich who have worked in gentler times. Here I might refer to a blasphemy trial in Cape Town in 1967-1968, when the editor of a student newspaper was tried for including in a report on a YMCA debate on the subject 'Is God dead' attributes 'inappropriate to the Supreme Being'. The prominent Catholic and Anglican theologians who spoke for the defence bewildered the magistrate with what they had to say about Tillich, Bonhoeffer, and John Robinson. The action had been initiated by the Special Branch. The outcome was that the Editor was found guilty but conditionally discharged, the prosecutor was presently promoted to the Bench, and the Special Branch took the blasphemy law off its list of weapons.

${ }^{61} C f$. Wright 2005, esp. 193 on the on-going threads of Stoic pantheism, Epicurean 'deism' and the scepticism or agnosticism of the Academicians. 
society. Some were quite capable of actively supporting ruler cult, and Seneca serves to illustrate that a Stoic could be equally capable of seeing the funny side of, for instance, imperial apotheosis. When a Thrasea Paetus faced the wrath of an emperor it was for his principled stand in defence of moral issues, ${ }^{62}$ and not for his theological, or rather ontological beliefs. For Paul the challenge was no doubt very real and purposeful, but we may suspect that for his Stoic and Epicurean challengers this was little more than a public debate. Had they taken a narrow focus on their respective cosmological theories, that could have been an interesting three-cornered debate, but they chose to represent the religious commonplaces which framed the cults, rites and conventions of the community. For the purposes of this action they adopted the role of concerned, conservative citizens, which St Paul seems to have countered successfully. One may fancy that for his challengers this debate had a secondary deeper level of meaning with positions representing rationalism, empiricism, and faith.

\section{BIBLIOGRAPHY}

Atkinson, J E 2006. Ethnic cleansing in Alexandria AD 38. Acta Classica 49:3154.

Bailey, C 1928. Karl Marx on Greek atomism. CQ 22:205-206.

Bailey, C 1947. Titi Lucreti Cari De rerum natura libri sex, Vol. 2. Oxford: OUP. Barnes, T D 1969. An apostle on trial. JTS 22:407-419.

Bechard, D P 2000. Paul outside the walls: A study of Luke's socio-geographical universalism in Acta 14.8-20. Rome: Biblical Institute Press.

Blaiklock, E M 1959. The Acts of the Apostles. London/Grand Rapids: Eerdmans.

Bowersock, G W 1965. Augustus and the Greek world. Oxford: OUP.

Chandler, C 2006. Philodemus On rhetoric Books 1 \& 2: Translation and exegetical essays. New York/London: Routledge.

Dibelius, M 2004. Paul on the Areopagus. In Hanson, K C (ed.), The book of Acts: Form, style, and theology, 95-128. Minneapolis: (Known to me indirectly.)

Dueck, D 2000. Strabo of Amasia, a Greek man of letters in Augustan Rome. London: Routledge.

Evans, N 2010. Civic rites: Democracy and religion in ancient Athens. Berkeley: University of California Press.

Farrington, B 1967. The faith of Epicurus. London: Weidenfeld \& Nicolson.

Fuhrmann, C J 2012. Policing the Roman empire: Soldiers, administration and public order. Oxford: OUP.

62 The regimes of Caligula, Nero and Domitian produced a number of brave souls, referred to as 'the Stoic opposition' who would 'speak truth to power': Fuhrmann 2012:139-140 for comment and source references. 
Geagan, D J 1997. The Athenian elite. In Hoff, M C \& Rotroff, S L (eds.), The Romanization of Athens. Oxford: Oxbow: 19-32.

Gigante, M 1995. Philodemus in Italy: The books from Herculaneum. Translated by D Obink. Ann Arbor: University of Michigan Press.

Gruen, E S 2002. Diaspora: Jews amidst Greeks and Romans. Cambridge, Ma.: Harvard University Press.

Haake, M 2007. Der Philosoph in der Stadt. Munich: Beck.

Haenschen, E 1956. Die Apostelgeschichte. Göttingen: Vandenhoeck \& Ruprecht.

Hammerstaedt, J \& Smith, M F 2014. The Epicurean inscription of Oinoanda. Bonn: Habelt.

Janko, R 2016. Review of Whitmarsh (2015). BMCR 2016.06.20.

Jones, C P 2003. Epigraphica VI-VII. ZPE 144:157-163.

Jones, C P 2009. Review of Haake (2007). Gnomon 81:521-524.

Keener, C S 2014. Acts: An exegetical commentary. Vol. 3:15:1-23:35. Grand Rapids: Baker Academic.

Marshall, I H 1980. The Acts of the Apostles: An introduction and commentary. Grand Rapids: Eerdmans.

Morgan, T 2007. Popular morality in the early Roman Empire. Cambridge: CUP.

Noble, B et al. 1971. The Acts of the Apostles. Philadelphia: Westminster / Oxford: Blackwell.

Ostwald, M 1986. From popular sovereignty to the sovereignty of the law. Berkeley: University of California Press.

Pervo, R L 2009. Acts: A commentary, edited by H W Attridge. Minneapolis: Fortress.

Pope, M W M 1986. Epicureanism and the atomic swerve. Symbolae Osloenses 61:77-97.

Preece, M R 2013. Acts 17: Paul before the Areopagus. MA thesis. Brigham Young University.

Roskam, G 2007. Live unnoticed: On the vicissitudes of an Epicurean doctrine. Leiden/Boston: Brill.

Rowe, C K 2009. World upside down: Reading Acts in the Graeco-Roman age. Oxford: OUP.

Schmalz, G C R 2009. Augustan and Julio-Claudian Athens. Leiden/Boston: Brill.

Sherwin White, A N 1963. Roman society and Roman law in the New Testament. Oxford: OUP.

Smallwood, E M 1966. Documents illustrating the Principates of Nerva, Trajan and Hadrian. Cambridge: CUP.

Smallwood, E M 1967. Documents illustrating the Principates of Gaius, Claudius and Nero. Cambridge: CUP. 
Smallwood, E M 1981. The Jews under Roman rule, from Pompey to Diocletian. Reprinted with corrections. Leiden: Brill.

Smith, M F 1963. Diogenes of Oinoanda: The Epicurean inscription. Naples: Bibliopolis.

Spawforth, A J S 1997. The early reception of imperial cult in Athens. In M C Hoff \& S I Rotroff (eds.), The Romanization of Athens. Oxford: Oxbow: 183201.

Still, T D 1999. Conflict at Thessalonica. Sheffield: Sheffield Academic Press.

Swain, S 1996. Hellenism and Empire: Language, classicism and power in the Greek world, AD 50-350. Oxford: OUP.

Thom, J C 2005. Cleanthes' Hymn to Zeus. Tübingen: Mohr Siebeck.

Too, Y L \& Livingstone, N (eds.) 1998. Pedagogy and power: Rhetorics of classical learning. Cambridge: CUP.

Traill, J S 1975. The political organization of Attica: A study of the demes, trittyes and phylai. Princeton: American School of Classical Studies at Athens.

Whitmarsh, T 1998. Reading power in Roman Greece. In Too \& Livingstone 1998: 192-213.

Winter, B W 2015. Divine honours for the Caesars: The first Christians' responses. Grand Rapids/Cambridge: Eerdmans.

Wright, N T 2005. Doubts about doubt: Honest to God forty years on. Journal of Anglican Studies 3.2:181-196. 